\title{
EL FUNCIONARIO COMO EXPERTO. PROFESIONALISMO Y DILETANTISMO EN LA FUNCIÓN PÚBLICA DE LA GENERALITAT DE CATALUNYA (1931-1939)'
}

\section{The official as an expert. Professionalism and diletantism in the public function of the Generalitat of Catalonia (1931-1939)}

\author{
DAVID MARTÍNEZ FIOL \\ Universitat Autònoma de Barcelona \\ Universitat Oberta Catalunya \\ GRENS - Universitat Pompeu Fabra \\ David.Martinez.Fiol@uab.cat
}

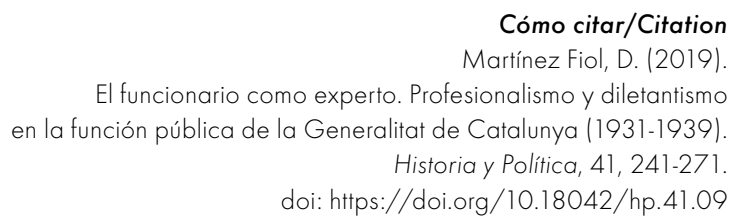

(Recepción: 01/07/2017; Evaluación: 11/10/2018; Aceptación: 10/01/2018; Publicación: 13/05/2019)

Resumen

La Espańa de la primera mitad del siglo xx operó un intenso proceso de modernización política y económica que se tradujo en el crecimiento de las zonas urbanas y del sector de los servicios. Este fenómeno facilitó la expansión de una

Este artículo forma parte del proyecto colectivo de investigación “Fisión” y "Fusión” estatales en los sistemas políticos contemporáneos: el excepcionalismo y los cambios de fronteras». HAR2015-67658-P (MINECO/FEDER, UE). También cuenta con el apoyo del grupo de investigación consolidado reconocido por la AGAUR: Grup d'Estudi de les Institucions i de les Cultures Politiques (S. XVI-XX). Referencia: (2017 SGR 1041). 
nueva clase media con estudios universitarios que optó, como medio de supervivencia económica y promoción social, por ofrecer sus servicios a las diferentes Administraciones públicas existentes en España. En el caso de Cataluña, la concreción de la Mancomunitat primero, en 1914-1924, y de la Generalitat después, en 1931-1939, abrió una ventana de oportunidades laborales a estas clases medias de formación universitaria. Sin embargo, en la construcción de la Generalitat republicana no siempre el mérito académico y profesional fue el requisito imprescindible en la contratación de funcionarios. La lucha contra la monarquía de Alfonso XIII y el régimen primorriverista sirvieron para algunos sectores del espacio político catalanista como carta de presentación suficiente para la obtención de un empleo público. Este artículo analiza cómo se construyeron, en la Cataluña de los años treinta, los diferentes discursos sobre cómo debía ser el auténtico profesional de la Administración pública de la Cataluña autónoma.

\section{Palabras clave}

Profesionalismo; corporativismo; sindicalismo; Segunda República; función pública.

\section{Abstract}

The Spain of the first half of the twentieth century operated an intense process of political and economic modernization which resulted in the growth of urban areas and the services sector. This phenomenon facilitated the expansion of a new middle class with university studies chose as a means of economic survival and social promotion, offer their services to the different public administrations existing in Spain. In the case of Catalonia, the realization of the Mancomunitat first in 19141924 and in 1931-1939 the Generalitat then opened a window job opportunities to these middle classes of university education. However, in the construction of the Republican Generalitat, not always academic merit and professional it was the prerequisite for the recruitment of officials. The struggle against the monarchy of Alfonso XIII and the regime primoriverista served for some sectors of the Catalan political space as a letter of presentation sufficient to obtain public employment. This article analyzes how were built in Catalonia in the thirties, different discourses on how it should be genuine public administration professional in the Catalonian self-goverment.

\section{Keywords}

Professionalism; corporatism; syndicalism; Second Republic; public function. 


\section{SUMARIO}

I. INTRODUCCIÓN. II. BARCELONA: CENTRO RECEPTOR DE FUTUROS FUNCIONARIOS CATALANISTAS. III. AMIGUISMO Y PROFESIONALIDAD EN LA CONSTRUCCIÓN DE LA FUNCIÓN PÚBLICA DE LA GENERALITAT. IV. EL FUNCIONARIO DE LA GENERALITAT VISTO POR FUNCIONARIOS DE LA GENERALITAT. V. LA PERVIVENCIA DEL CESANTE. VI. LA REVOLUCIÓN DE LOS FUNCIONARIOS DILETANTES. VII. EL DILEMA DE LA CNT. VIII. CONCLUSIÓN. BIBLIOGRAFIA.

\section{INTRODUCCIÓN}

Durante el siglo XIx, la construcción del Estado liberal en España se caracterizó por el triunfo del elitismo político y social frente a la meritocracia profesional. La opinión pública española visualizó a su clase política como un conjunto de profesionales de la misma dispuestos a mantenerse en sus cargos al precio que fuese, aunque este precio fuese la "desmovilización» de las masas a través de un reducido censo electoral o de unas leyes de asociación sumamente restrictivas en su aplicación normativa. En este sentido, el Estado fue percibido como el coto privado de una élite liberal ennoblecida al cual solo se podía acceder por la vía de la influencia y de los amigos políticos. De esta forma, el cuerpo de funcionarios que se concretó durante la era isabelina, el Sexenio Democrático y la primera Restauración alfonsina se caracterizó por su débil profesionalización, ineficacia o diletantismo. Sin embargo, este aspecto es matizable en la medida que la ineficacia y diletantismo de los funcionarios debe también considerarse fruto de una Administración estatal poco desarrollada e ineficazmente intervencionista en la vida pública española. Por tanto, es necesario matizar que la ineptitud funcionarial denunciada por los críticos del sistema liberal imperante era también consecuencia de la lejanía existente entre la Administración pública y sus administrados. El propio discurso administrativista del franquismo, profundamente antiliberal, no dudó, paradójicamente, en reconocer, casi cien ańos después, y en palabras de Laureano López Rodó, la amplía política legislativa ejercida por los diferentes Gobiernos liberales en materia de ferrocarriles, aguas, bosques, caminos, industria, agricultura, orden público y social. Y, sin embargo, López Rodó pasaba página del tema de la función pública y de la misma enseñanza, en una velada admisión del fracaso del Estado (y más en concreto, del Estado liberal) en estas materias, señalando: 
«De intento he dejado fuera de la enumeración las disposiciones relativas a enseñanza y a funcionarios $»^{2}$.

La crisis del final del siglo xIx desató las críticas contra la Restauración alfonsina, las cuales dieron lugar a una serie de exigencias políticas y socioprofesionales. En el terreno político destacaba la necesidad de democratización del sistema liberal español a través de la limpieza electoral del sufragio universal. En el ámbito socioprofesional y, en concreto, en el de la administración del Estado suponía la instauración del principio de igualdad de oportunidades para todos los españoles en el acceso de la función pública. Significaba, más en la retórica regeneracionista que en la estricta realidad, poner fin a una función pública que se consideraba plagada de enchufados, amigos y recomendados de los políticos para situar en su lugar a profesionales bien preparados y de procedencia universitaria o, fundamentalmente, con estudios de bachiller. Estos sectores ilustrados y tecnificados procedían de unas clases medias en expansión numérica y profesional como consecuencia del proceso de transformación urbana que España empezó a operar en los últimos ańos del siglo xix y principios del $\mathrm{xx}^{3}$.

De esta forma, durante los años 1898 y 1936 se concretó en la Administración pública española un cambio en el proceso de contratación y de formación de los funcionarios públicos en el que empezaron a imponerse lentamente los méritos profesionales por encima de los méritos personales y afectivos. Desde este punto de vista hay que entender, sin duda, la eclosión del asociacionismo profesional y funcionarial que se produjo en Espańa durante la primera mitad del siglo xx. Ciertamente, la vocación expansiva en este periodo de la Administración del Estado tuvo como consecuencia una amplia demanda de expertos en gestión pública que se concretó en una cada vez más tecnificada y compartimentada —y, por tanto, corporativizada - función pública. Aquellos ámbitos de la Administración que más ampliaron sus plantillas y se extendieron por el territorio español fueron Correos y el personal de los ministerios de Hacienda y Justicia. Y fue precisamente en estos sectores donde se concretaron influyentes organizaciones corporativas en defensa de sus espacios de promoción social y profesional en forma de juntas, especialmente en los años diez y, más en concreto, en los años previos a la gran crisis política de 1917, y que tuvo su punto álgido con la huelga de Correos de marzo de 1918 (coincidente con las elecciones generales) y el decreto de Estatuto de Funcionarios del mismo año ${ }^{4}$.

\footnotetext{
López Rodó (1963): 69; García de Enterría (1972), y Nadal (1987).

3 Para Valencia, Sirera Miralles (2011).

4 La normativa elaborada al entorno de la función pública española en el primer tercio del siglo xx: Villacorta Baños (1989). Sobre la huelga de Correos: «La Huelga de
} 
Paralelamente al crecimiento de la función pública estatal española, los diferentes sectores del catalanismo ejecutaron un discurso (coincidente con el del republicanismo, el socialismo y el mismo maurismo o el de un sector del Ejército) en el que se afirmaba la crisis irreversible del Estado español y la necesidad imperiosa de reformarlo o, incluso, de cambiarlo en su totalidad. En la práctica se tradujo en la idea de configurar una Administración autónoma para Cataluña, que comportase la vertebración de un cuerpo propio de funcionarios y profesionales: en su lógica discursiva, los catalanistas no dudaron en resaltar que, frente a lo que ellos consideraban una ineficaz y poco profesional función pública española, ellos apostaban por un cuerpo de empleados públicos catalanes, arraigados en el territorio catalán y de solvencia académica contrastada. Una apuesta que tuvo su primera gran formulación política en las Bases de Manresa y que se fue concretando de forma efectiva, aunque con muchos matices, en la Administración local del Estado en Cataluña, ya fuese en las diputaciones provinciales, la Mancomunitat o la Generalitat 5 .

\section{BARCELONA: CENTRO RECEPTOR DE FUTUROS FUNCIONARIOS CATALANISTAS}

Para entender la organización de la función pública de la Mancomunitat (1914-1925) y de la autonomía regional de Cataluña (1931-1939) hay que considerar el peso social, cultural y económico que la ciudad de Barcelona ejercía y ha ejercido a lo largo de la contemporaneidad en el conjunto del principado catalán. Ciertamente, las diferentes propuestas catalanistas presentaban a Barcelona como un contrapoder alternativo a Madrid. Incluso, en algunas formulaciones no se dudaba en hablar de una dualidad capitalina al estilo del Imperio austro-húngaro, donde Madrid ejerciese de Viena y Barcelona de Budapest. Según los intelectuales catalanistas, una posible corona dual espańola podía permitir a los catalanes dotarse de una Administración pública propia y gestionada desde Cataluña sin el coste de una ruptura de la nación española 6 .

Sin embargo, la propuesta del dualismo catalanista únicamente despertó desconfianza entre la clase política espańola y las clases medias madrileñas al

Correos y Telégrafos», El Sol, 24-2-1918, p. 1, y «Extrema decisión del Gobierno / Disolución de los Cuerpos de Correos y de Telégrafos / Las Juntas Militares continúan su actuación», El Sol, 17-3-1918, p. 1. Véase: Martínez y Esculies (2017).

5 Bases per a la Constitució Regional Catalana (1991). El papel del Ejército en las bases, en Pérez Francesch (1988).

6 Ucelay-Da Cal (1984) y Llorens i Vila (1992). 
ver a Barcelona como una rival en la competencia por el mercado de trabajo del sector terciario. Y es que, en realidad, existía otro problema de índole socioeconómica: de siempre, Madrid se presentó y actuó como la ciudad que monopolizaba la gran oferta del sector de los servicios públicos a partir de su condición de capital del Estado. En otras palabras, la fuerza de Madrid residía en su numerosa burocracia generada por los ministerios y sus oficinas. Pero sin estas, Madrid no era gran cosa porque, a diferencia de Barcelona, carecía de un hinterland industrial que pudiera servir de atracción de mano de obra forastera en caso de dejar de ser capital del Estado, como así sucedió durante la Guerra Civil 7 . Por otro lado, la concreción de una función pública estrictamente catalana no iba a hacer otra cosa que limitar la fuerza y presencia de los ministerios madrileños en Cataluña. En este sentido, uno de los sectores que peor se tomó la posibilidad de crear una función pública catalana fue el Ejército, que vio en los catalanistas unos rivales sempiternos por el control de la Administración pública ${ }^{8}$.

Pero ¿cómo se concretó en Cataluña esta tendencia notable a la terciarización de la economía y de la sociedad? En primer lugar, el crecimiento industrial que Cataluña había efectuado durante el siglo xix encontró su freno en la crisis colonial de 1898. El proceso industrializador de Cataluña se había fundamentado en una industria de bienes de consumo, fundamentalmente textiles, y había dejado de lado cualquier incursión en los bienes de equipo. Esto significaba la necesidad de poseer un mercado consumidor permanente y efectivo concretado en las colonias americanas y las Filipinas 9 . Perdido este mercado en 1898, la industria textil catalana sufrió un periodo de cierta readaptación que trajo consigo una importante conflictividad social (terrorismo anarquista o la huelga de 1902) ${ }^{10}$. En este sentido, una vía de recuperación industrial fue la incursión e inversión de los hombres de negocio catalanes en el sector de la construcción, transportes o electricidad a partir del potente crecimiento urbano y humano que sufre la ciudad de Barcelona durante el periodo 1900-1930. Ello implicó el incremento de la oferta de empleos técnicos en el mundo de la empresa y, por consiguiente, una potenciación de la formación profesional ${ }^{11}$. En este proceso de tecnificación de la sociedad catalana tuvieron un papel destacado los abogados, médicos, arquitectos, ingenieros..., los cuales encontramos

\footnotetext{
Bahamonde Magro (1992); García Delgado (1992), y Juliá (1992).

Solé y Villarroya (1990 y 1987).

Carreras (1990); Nadal (1975); Nadal i Oller (1991), y Deu i Baigual (1990).

Ramos y Bengoechea (1989) y Romero Maura (1989).

11 Sobre los cuadros intermedios de las empresas fabriles catalanas: Smith (1995 y 1996); Duarte (1989), y Alberdi (1983).
} 
vinculados al mundo del catalanismo político y, principalmente, de la conservadora Lliga Regionalista ${ }^{12}$. Este sector debería considerarse como la élite tecnocrática que puso las bases de una Administración pública catalana que tendría su primera experiencia constatable en la Mancomunitat de Cataluña ${ }^{13}$.

Por otro lado, la tendencia a la terciarización de la sociedad catalana tuvo como segundo factor la crisis agraria de finales del siglo XIX y que abocó a muchos jóvenes procedentes de familias campesinas arrendatarias o con pequeñas propiedades a abandonar las tierras que habían cultivado sus padres y abuelos. El destino tradicional de la migración agraria catalana siempre fueron las tierras americanas ${ }^{14}$. Sin embargo, el proceso expansivo de Barcelona en el primer tercio del siglo xx, ayudó a minimizar la fuga a las Américas. Desde ese momento, Barcelona podía ser percibida como una ciudad de oportunidades, no solo para jóvenes de familias campesinas arrendatarias o con pequeñas propiedades e hijos de la menestralía catalana dispuestos a triunfar en lo que sea, sino también para aragoneses, valencianos y, en menor medida, baleáricos ${ }^{15}$. Buena parte de estos jóvenes aspiraban a situarse en el sector de los servicios y no en el mundo del trabajador manual. No querían trabajar en la construcción, sino que aspiraban a conseguir algún empleo vinculado al mundo de los negocios o el sector terciario. Si se iba a Barcelona era para triunfar, no para hacer lo mismo que en el campo: ganarse la vida con las manos. Y en esta vía existían algunos que, fascinados por la bohemia barcelonesa y sus artistas e intelectuales modernistas, apostaron por vivir del periodismo e, incluso, llegar a ser escritores de prestigio ${ }^{16}$. Pero tenían un terrible handicap con respecto a sus admirados artistas bohemios y modernistas. Algunos, como Santiago Rusiñol, pertenecían a familias selectas de la burguesía barcelonesa y, por esa razón, podían permitirse el lujo de vivir la bohemia sin arruinarse y sin preocuparse del sustento diario. Los jóvenes campesinos llegados a Barcelona eran unos «don nadie» aún por demostrar muchas cosas tanto en el terreno profesional como en el intelectual. Es más, tenían una segunda limitación: tampoco podían competir con los técnicos superiores próximos a la Lliga puesto que, a diferencia de estos, no eran universitarios y sí ciertamente iletrados: fue el caso de Daniel Domingo Montserrat, de familia de pescadores de Tortosa, nacionalista radical macianista y primo del republicano y futuro ministro de la Segunda República ${ }^{17}$, Marcelino Domingo.

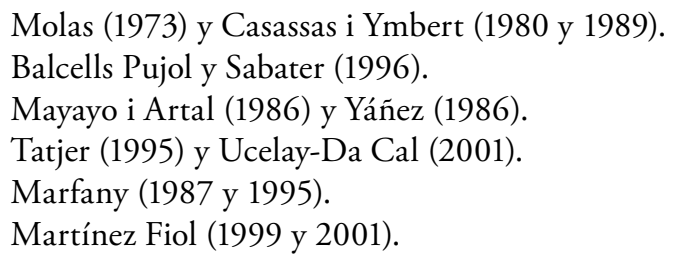


Así, los jóvenes campesinos y menestrales tuvieron que aceptar el juego de promoción socioprofesional marcado por las clases medias catalanas y catalanistas del primer tercio del siglo xx. Un juego de promoción que había marcado el catalanismo conservador y que se había circunscrito fundamentalmente a los profesionales con título universitario, pero también con bachiller. Ciertamente, el gran objetivo del catalanismo, pero en especial de la Lliga Regionalista, fue el control de la Administración local de Cataluña. Primero a través de las diputaciones provinciales, estrictamente las de Barcelona y Girona entre 1907 y 1913. Posteriormente, con la concreción de la Mancomunitat entre 1914 y 1925, controlaron el conjunto de las cuatro diputaciones ya mancomunadas. Para este objetivo, los intelectuales regionalistas diseñaron todo un proyecto político-cultural, el Noucentisme, que debía ser ejecutado por una pléyade de intelectuales-profesionales y funcionarios de adscripción catalanista que deberían ser formados en la denominada Escuela de Administración Local de Cataluña. Para ello se contrataron profesores procedentes de todos los ámbitos del catalanismo especializados con titulación universitaria en Derecho, Contabilidad, Economía y Administración Pública, siendo dirigida la escuela por personajes procedentes de la Lliga Regionalista como Isidre Lloret y Josep M. Pi i Sunyer ${ }^{18}$.

Frente a este estado de cosas, los jóvenes campesinos y menestrales, imposibilitados económicamente para ingresar en un instituto de bachillerato y ni mucho menos en la universidad, no tuvieron otro remedio que formarse académicamente de forma autodidacta a través de casas del pueblo, ateneos populares o centros catalanistas ${ }^{19}$. Despechados, separatistas, libertarios y republicanos catalanes coincidieron en afirmar que la Lliga Regionalista y la Mancomunitat era la «oligarquía y caciquismo» de Cataluña. Con todo, la Mancomunitat, a pesar de no romper el marco provincial del Estado, fue convertida por el catalanismo en un contrapoder molesto para los militares y la Capitanía General de Cataluña, lo que se dio en llamar como el Partido Militar ${ }^{20}$. Y también fue un inconveniente para la propia Administración gubernativa del Estado representada por los gobiernos civiles y las diputaciones ${ }^{21}$. No ha de extrañar, por tanto, que una de las primeras actuaciones de la dictadura de Primo de Rivera, entre 1923 y 1925, fuese cambiar el personal político de la Mancomunitat en beneficio de la Unión Monárquica Nacional ${ }^{22}$.

\footnotetext{
18 Sarrión i Gualda (1982); Casassas i Ymbert (1989), y Diputación Provincial de Barcelona (1915).

19 Lladonosa i Vall-Llebrera (1988) y Solà (1978).

20 Calvo (1974); Cardona (1983); Boyd (1990), y Casals (2013).

21 Ucelay-Da Cal (1987) y Risques (1995).

22 Joaniquet (1955) y Puy (1983).
} 
Por todas estas razones, republicanos y catalanistas radicales apostaron por una nueva Administración local y regional para Cataluña que debía plasmarse en un Estatuto de Autonomía que fuese compatible con una República federal. Aun así, la fuerza de la Lliga durante los primeros veintitrés años del siglo $\mathrm{xx}$ fue tan poderosa que republicanos y catalanistas radicales se sumaron al proyecto institucional de la Mancomunitat y optaron por la carrera funcionarial como vía de promoción política y profesional. Pero no todos lograron ese objetivo, lo cual acrecentó la radicalidad de los denominados separatistas, que cada vez más se sintieron fascinados por el insurreccionalismo irlandés. Esta vocación insurreccionalista de los separatistas catalanes liderados por Francesc Macià conectaría durante los ańos veinte con el insurreccionalismo aventurero de los anarquistas, ayudando a poner las bases de una confluencia política que derivaría en Cataluña, en abril del 1931, en la proclamación de la República catalana y su posterior conversión en Generalitat de Cataluña. El nuevo contexto político catalán dominado por la Esquerra Republicana de Catalunya (una síntesis de catalanistas radicales y republicanos catalanes) surgido del establecimiento de la Segunda República impuso unas reglas de promoción política y profesional marcadas por el conocimiento y el uso de la lengua catalana ${ }^{23}$.

En este sentido, no difería en absoluto de las reglas del juego ya establecidas por la Lliga en la Mancomunitat. Pero ahora las bases de la Esquerra Republica de Catalunya (ERC) aspiraban a sustituir dentro de la nueva Administración pública autónoma de Cataluña a los técnicos universitarios regionalistas. El problema, el cual daría lugar a unos duros enfrentamientos entre la Lliga y la ERC, era que la nueva tecnocracia republicana y separatista no había surgido en su conjunto de las universidades y las escuelas secundarias del Estado, sino que se había forjado mayoritariamente, de forma autodidacta, en ateneos, casas del pueblo y centros catalanistas. A los ojos de los regionalistas, la nueva tecnocracia republicana y funcionarial de Cataluña lo era más por méritos políticos (haber luchado contra la monarquía) que por méritos académicos y profesionales ${ }^{24}$.

\section{AMIGUISMO Y PROFESIONALIDAD EN LA CONSTRUCCIÓN DE LA FUNCIÓN PÚBLICA DE LA GENERALITAT}

Ciertamente, los dirigentes de la Lliga Regionalista no estuvieron exentos de razón cada vez que criticaron la forma en que buena parte de los altos

23 Vallverdú (1970, 1972 y 1990) y Duarte i Montserrat (1984).

24 Assemblea General de la Lliga Regionalista (1933). 
cargos políticos de la Generalitat y de sus funcionarios accedieron a la Administración de la autonomía regional catalana. Sin duda, la afinidad política con los dirigentes de ERC fue un factor de promoción profesional dentro de la función pública de la Generalitat. Pero también es cierto que el primer presidente de la Generalitat republicana, Francesc Macià, era sumamente consciente de que en las filas de su recién fundado partido, Esquerra, existían muy pocos intelectuales profesionales con estudios de bachiller o universitarios preparados para ejercer funciones de gestión administrativa y de liderazgo político. De esta forma, Macià no tuvo más remedio que seguir contando con la colaboración de funcionarios y altos cargos de la Administración vinculados a Acció Catalana y la Lliga Regionalista, sus más inmediatos rivales electorales del centro y la derecha catalanista respectivamente. Este hecho supuso un elemento más de fricción entre Macià y aquellos sectores de su partido, sobre todo los más nacionalistas radicales, desencantados por la desaparición el 17 de abril de 1931 de la República catalana, asumida esta, en el imaginario separatista, como más catalanista que la propia Generalitat. Estos sectores separatistas fueron abandonando ERC y sus juventudes a lo largo de 1931, convencidos de que Macià no iba a llevar a cabo la anhelada revolución catalanista y obrerista que les hubiera conducido a una especie de Estado libre Catalán de características similares al establecido por el Reino Unido en Irlanda en 1921, creando sus propias alternativas culturales, políticas y profesionales, a través de formaciones como el Bloque Obrero y Campesino (BOC), el Partit Comunista Català (PCC), el Partit Català Proletari (PCP), Nosaltres Sols! o el Partit Nacionalista Català (PNC), con el fin de arrebatar la autonomía catalana y su administración a Esquerra Republicana de Catalunya ${ }^{25}$.

Sin embargo, la marginalidad de estas alternativas y la aprobación de un Estatuto de Autonomía en 1932 condujeron a que una parte importante de los jóvenes separatistas disidentes con Macià pronto volvieron al «hogar paterno» de ERC. La perspectiva que suponía la construcción de un «Estado autónomo» catalán (como así les gustaba llamar a algunos sectores catalanistas a la legalmente considerada autonomía regional) como una fábrica de empleos públicos facilitó el reingreso de muchos de estos nacionalistas radicales hacia el seno de ERC, comportando en algunos casos su inmediato nombramiento como funcionarios de la Generalitat. Muchos de estos nuevos empleados no poseían ni estudios universitarios ni secundarios. Es más, algunos solo podían aducir que habían cursado estudios elementalísimos no reglados en las escuelas del CADCI (Centre Autonomista del Comerç i de la Indústria) o de algunos centros obreros republicanos y catalanistas. Para formalizar el acceso de

25 Ucelay-Da Cal (1978); Bonamusa (1974); Durgan (1996), y Tubella (1979). 
estos nuevos funcionarios, la Generalitat dispuso de unos cursillos de breve duración que debían acreditar su valía como empleados públicos. A modo de excepción encontramos a Jaume Miravitlles, que se convirtió, además, en el presidente de la influyente Associació de Funcionaris de la Generalitat de Catalunya (AFGC), una entidad corporativa que agrupaba a la mayor parte de los funcionarios de la Generalitat y que estuvo hasta 1936 bajo la influencia de $\mathrm{ERC}^{26}$.

La funcionarización masiva de los «amigos políticos» de Macià provocó las críticas airadas de la Lliga Regionalista en el Parlamento autónomo de Cataluña. Según los regionalistas, ERC y sus aliados de la Unió Socialista de Catalunya habían aprovechado su mayoría absoluta en el Parlamento autónomo para establecer un cuerpo legislativo que favoreciese el acceso a la función pública de la Generalitat de aquellos que eran considerados «amigos políticos» de ERC. Así, el diputado regionalista Tomàs Carreras i Artau, en sesión del Parlamento de Cataluña de 7 de diciembre de 1933, hizo llegar al Gobierno de Cataluña una queja sobre la forma en que se habían contratado y se seguían contratando los profesores de los instituts-escola de la Generalitat. Afirmaba que se contrataban por el sistema de nombramiento directo, confundiendo este con el denominado «nombramiento extraordinario». Hay que señalar que el nombramiento directo lo ejercía fundamentalmente el presidente de la Generalitat con el objetivo de cubrir las vacantes de los cargos que, como las direcciones generales, tenían un carácter más político que técnico. En cambio, el nombramiento extraordinario se utilizaba cuando una vacante la podía cubrir una personalidad reconocida y admirada por el conjunto de la comunidad académica e intelectual de Cataluña. En este caso, un comité científico establecía si una cátedra o una plaza de profesor de un institut-escola podía cubrirse sin necesidad de que se convocaran oposiciones a la misma, siempre y cuando el candidato escogido por el comité científico poseyera solvencia profesional-intelectual y prestigio público. El problema que denunció Carreras i Artau fue que se realizaban contratos docentes para los instituts-escola a través del procedimiento del nombramiento directo haciéndolos pasar ante la opinión pública como si fuesen de nombramiento extraordinario. Esta confusión en la categoría del nombramiento resultaba grave, puesto que había permitido contratar, sin ningún tipo de control académico, a muchísimos profesores sin ningún tipo de pedigrí intelectual y técnico. En consecuencia, Carreras i Artau denunció que resultaba vergonzoso que Pompeu Fabra, que había accedido a la función pública docente por la vía extraordinaria a través de la evaluación de un comité científico, se encontrase en una situación

26 Martínez Fiol (2006, 2008 y 2010). 
laboral y profesional equiparable a la de numerosos diletantes que habían ocupado sus puestos de trabajo público a través de un nombramiento directo.

Asimismo, la Lliga denunció en el Parlamento catalán el poco valor académico que los Gobiernos de la Generalitat formados por ERC dieron a la Escola d'Aministració Local de Catalunya. En sesión del 11 de abril del 1933, el diputado de la Lliga Miquel Vidal i Guardiola indicó un poco exageradamente que la normativa establecida por la autonomía regional catalana priorizaba como mérito para el acceso a la función pública el «amiguismo». Vidal consideraba que se despreciaba el plan de estudios correspondiente a la licenciatura de Funcionario de Administración Pública y, en cambio, se potenciaban cursillos de corta duración y fácil obtención que permitían adquirir la condición de funcionarios fijos de la Generalitat a los empleados interinos. En la crítica del diputado regionalista estaba implícita la identificación entre interino e inexperto y enchufado, mientras que el licenciado de la Escola d'Administració Pública de Catalunya equivalía a técnico y profesional.

A pesar de las críticas regionalistas, durante el verano de 1933 se continuaron realizando cursillos de tres meses con el objetivo de adecuar la situación laboral y académica de numerosos funcionarios de la Generalitat contratados provisionalmente durante el primer bienio de la República. Es más, el 19 de diciembre del 1933 el Parlamento de Cataluña aprobó un decreto por el cual el personal temporal que tuviese un año o más de servicio en la Generalitat o en la antigua Diputación de Barcelona podía acceder de facto a la plantilla de la Generalitat. En conjunto, el cursillo de verano y el decreto de diciembre de 1933 representaron un golpe moral a la utilidad y a la credibilidad académica de la Escola d'Administració Local de Catalunya creada por la Lliga en $1912^{27}$.

\section{EL FUNCIONARIO DE LA GENERALITAT VISTO POR FUNCIONARIOS DE LA GENERALITAT}

Durante el periodo 1931-1936, los funcionarios de la Generalitat se encuadraron corporativamente en la Associació Cultura i Esport-Generalitat de Catalunya (ACE-GC) y la Associació de Funcionaris de la Generalitat de Catalunya (AFGC). La primera extendió su vida afiliativa entre 1931 y 1933, mientras que la segunda lo hizo desde 1933 hasta 1938. Ambas entidades cabe considerarlas como una misma organización en la medida en que el cambio de denominación de ACE-GC por AFGC fue acordado por los propios asociados

27 Sarrión i Gualda (1982): 266-271. 
en una junta de la entidad. En este sentido, cabe resaltar que la ACE-GC y la AFGC estuvieron dirigidas por funcionarios vinculados a la USC o la ERC, sin que ello fuese un impedimento para la afiliación de empleados simpatizantes de Acció Catalana o la Lliga Regionalista, como fue el caso de los escritores Carles Soldevila o Josep M. López-Picó. Ambas entidades publicaron un boletín informativo y de opinión en el cual no solo se planteaban las mejoras salariales y laborales de rigor, sino que también se hacía hincapié en aquellos aspectos que debían definir al funcionario como un experto en la función pública. Así, en el primer número del Butlletí de l'ACE-GC de mayo de 1932, Carles Soldevila hacía una exaltación del papel del Estado como ente ordenador de la vida pública y de la figura del funcionario eficiente:

Els funcionaris, estimats amics, tenim una situació que és una veritable paradoxa. D'una banda, som un rodatge cada dia més necessari, cada dia més indispensable dins una societat que tendeix a confiar cada dia més afers i més interessos al poder públic. D’una altra banda, som mirats amb recel i fins amb hostilitat per bona part dels nostres conciutadans que ens suposen beneficiaris de qui sap quins privilegis i usurpadors de qui sap quines prerrogatives ${ }^{28}$.

En este sentido, las palabras de Carles Soldevila destacaban toda una serie de dudas e incertezas propias del periodo previo a la aprobación del Estatuto de Autonomía. Inicialmente, los funcionarios de la Generalitat fueron, en gran medida, los funcionarios de las antiguas diputaciones provinciales traspasados a la Generalitat provisional. Este funcionariado, y especialmente los adheridos a la ACE-GC, adoptaron una posición favorable a la consolidación del nuevo marco autonómico diseńado por ERC, puesto que también era la manera de mantener sus puestos de trabajo, aunque fuesen simpatizantes de Acció Catalana y de la Lliga. Ahora bien, esto podía comportar que los administrados llegaran a la conclusión desmoralizadora de que el cambio republicano de abril de 1931 no fuese más que una operación de maquillaje político en el cual se mantenía la corrupción del Estado y de su Administración, pero con unos nuevos gobernantes. Sin embargo, Soldevila realizó una lectura optimista indicando que el funcionariado existente en la Generalitat era cualificado porque poseía un alto nivel cultural:

Tenim dret, sens dubte, a demanar una rectificació d'aquest concepte que no s'adiu gaire amb la realitat. Però al mateix temps ens pertoca l'obligació de fer

28 C. Soldevila, «Pòrtic», Butlletí Cultura i Esport-Generalitat de Catalunya, núm. 1, Barcelona, 5-1932, p. 1. 
tot allò que puguem per treure la llegenda del funcionari que no té altra virtut que rosegar el pressupost i complicar l’administració pública, fins la darrera versemblança.

Aquesta tasca, amb sobtada dilatació de funcions que significa l'Estatut és alhora més urgent i més difícil. Més urgent perquè ara més que mai cal que els funcionaris catalans inspirin confiança i simpatia; més difícil perquè la rapidesa amb que serà necessari crear o conjuntar els òrgans administratius nous implicarà probablement un període de vaguetat reglamentària, de provisorietat d'orientacions i un ingrés copiós de buròcrates novells...

No hi fa res. El deure no minva pas perquè creixin les dificultats que s'oposen al seu compliment. En l'hora d'iniciar Catalunya la seva vida autònoma, no hem de plànyer esforços per a crear-hi d'una manera sòlida i duradora un bell concepte del funcionari públic. Certament, tot no depèn de nosaltres; factors d'un altre ordre tindran una grossa responsabilitat. Però nosaltres cal que ens ocupem de la nostra ${ }^{29}$.

En conjunto, eficacia, deporte, cultura y guerra al sedentarismo a partir de una imagen dinámica de la Administración autónoma. Una obsesión en la cual incidió en el número siguiente del butlletí el poeta, funcionario y regionalista Josep M. López-Picó, resaltando la voluntad de servicio del funcionario por encima de los corporativismos egoístas y antisolidarios:

Avui, enfront de les facilitats humorístiques que han intentat la deformació del concepte del funcionari com una humanitat a part, presonera del personalisme de casta, monstruosa ampliació del jo, les paraules transcrites ens tornen el sentit de bon servei de la burocràcia catalana - la nostra - a favor d'una obra que continua, a l'esplendor de la qual cada individualitat, com més forta, més s'avé a l'íntima voluntat de creació col.lectiva, joc d'activitats i de realitats entre ahir i demà, articulació de tots els moments acceptats de cara al risc de les superacions i de les minves que són la totalitat vital de la nostra història i del nostre futur ${ }^{30}$.

En este sentido, la referencia a una «obra que continua» parecía matizar que, como antiguo funcionario de la Mancomunitat, debía resaltarse que la Generalitat era una continuación de la Mancomunitat. ¿Por qué? Porque era una manera de exigir sus méritos como antiguo funcionario de la Diputación de Barcelona, origen legal de la Generalitat. López-Picó también hacía uso de

29 Id.

30 J. M. López Picó, «Vida i oficina», Butlletí Cultura i Esport-Generalitat de Catalunya, núm. 2, Barcelona, 6-1932, p. 1. 
su categoría de viejo funcionario para desmarcarse de una aparente imagen de adhesión a ERC y a Macià afirmando que, en realidad, era leal a la Administración catalana autónoma y no a ERC.

\section{LA PERVIVENCIA DEL CESANTE}

La politización de la función pública fue en detrimento de su profesionalización efectiva. Ello no quita que realmente existiese un buen número de funcionarios que lo eran por méritos profesionales y técnicos. Ahora bien, una función pública en rápido crecimiento que necesitaba incrementar aceleradamente su personal para ofrecer los más diversificados servicios no tenía otra alternativa que contratar un número considerable de empleados temporales. Este personal temporal o temporero fue el más propenso a nutrirse de recomendados políticos. De esta forma, con cada cambio político (fuese después de unas elecciones o de una revolución frustrada, como la del 6 de octubre del 1934) los primeros en ser cesados o depurados de la función pública eran los empleados temporeros vinculados a la tendencia política que se quería castigar o arrinconar. En rigor, la Segunda República no supo romper con la figura del cesante o depurado. Sin embargo, esta figura no afectó exclusivamente al personal no funcionario y de nombramiento político, sino también a funcionarios de carrera

Cabe decir que las depuraciones y los ceses se hicieron más frecuentes a medida que las legislaturas parlamentarias se fueron acortando (1931-1933, 1933-1936). A ello hay que sumar las depuraciones que se realizaron después del fallido golpe del general José Sanjurjo en el verano de 1932 y de la fracasada revolución octubrista de 1934. En definitiva, tanta agitación depurativa impidió consolidar las plazas interinas como plazas orgánicas y construir una función pública profesionalizada y estable ${ }^{31}$.

Por su parte, el caso catalán no fue distinto al del resto de España. La autonomía regional catalana mantuvo entre abril de 1931 y octubre de 1934 una mayor estabilidad de plantilla que la Administración general debido a que ERC controló la Generalitat durante esos tres años sin ningún tipo de oposición política al ganar las elecciones autonómicas de noviembre de 1932 por mayoría absoluta, lo cual le permitía dominar el Gobierno y la Administración de la Generalitat ${ }^{32}$. Sin embargo, este dominio republicano catalanista se torció a raíz de la rebelión de la Generalitat del 6 de octubre de 1934, que

31 Martínez Fiol (2006).

32 Ucelay Da-Cal (1982). 
condujo al encarcelamiento del presidente de la Generalitat, Lluís Companys, y de la mayoría de sus consellers. La Generalitat, a pesar de la suspensión del estatuto, mantuvo sus constantes vitales bajo el control del Partido Republicano Radical, la CEDA y la Lliga Regionalista (que, desde 1933, se había rebautizado como Lliga Catalana). Esta nueva coalición gubernamental facilitó una depuración notable de funcionarios temporeros y de carrera de adscripción izquierdista para situar un nuevo contingente de empleados vinculados a la coalición gubernamental de derechas. La victoria electoral del Front d'Esquerres en Cataluña en febrero de 1936 trajo consigo una nueva oleada de cesantes, esta vez de derechas, y el restablecimiento de los funcionarios depurados durante el periodo octubre de 1934-febrero de 1936; situación que se vio rápidamente afectada por el inicio de la Guerra Civil ${ }^{33}$.

\section{LA REVOLUCIÓN DE LOS FUNCIONARIOS DILETANTES}

Uno de los grandes mitos de la guerra civil española es aquel que afirma que, en Cataluña, se llevó a cabo una auténtica revolución contra el Estado por parte de los sectores anarquistas vinculados a la CNT (Confederación Nacional del Trabajo) y a la FAI (Federación Anarquista Ibérica). Sin embargo, esta visión dista mucho de la realidad. De entrada, la CNT solo tuvo un auténtico protagonismo político en las jornadas revolucionarias de julio en la ciudad de Barcelona y su provincia. En el resto de Cataluña, el POUM le disputó con cierto éxito (fundamentalmente en Girona y Lleida) la hegemonía política $^{34}$. Por otro lado, la represión incontrolada y desorganizada de las patrullas de control y la acción individualista e insolidaria de las numerosas colectivizaciones surgidas durante el verano del 1936 desbordó a los dirigentes anarcosindicalistas, los cuales se sintieron, sin afirmarlo públicamente, incapaces de imponer un proyecto revolucionario con una fuerte y enérgica dirección ejecutiva ${ }^{35}$.

Ante este hecho, los dirigentes de la CNT no encontraron otra solución para salvar o reconducir la revolución que reconocer el Estado republicano y el conjunto de sus instituciones, en las que decidieron intervenir y participar.

33 Alquézar (1986 y 1988); Vinyes i Ribes (1983), y Martínez Fiol (2006).

34 Para Lleida-ciudad: Sagués San José (2004). Para la provincia de Lleida: Gimeno (1987); Pous y Solé (1988), y Prats i Armengol (1990). Para Girona: Adroher (1986) y Clara (2004).

35 Bernecker (1982); Monjo (1999); Seidman (2002); Cruells (1978), y Leval et al. (1982). 
Sin embargo, la incorporación de la CNT a las instituciones y la legalidad constitucional republicana se efectuó con la condición de no perder el control político obtenido, durante el verano de 1936, en aquellos lugares de la Administración del Estado y de las Administraciones locales y regionales en los que el anarcosindicalismo había conseguido situar a sus dirigentes, afiliados y simpatizantes. El problema que se derivó de este hecho fue que la función pública republicana se vio incrementada por una nueva clase de funcionarios que habían accedido a los empleos públicos a través de la fuerza de las armas y no por medio de unas oposiciones que pusiesen de manifiesto sus méritos profesionales ${ }^{36}$.

Ilustrativo de esta situación fue el caso de la autonomía regional de Cataluña. Así, a pesar del supuesto protagonismo de las masas, dirigidas por los anarcosindicalistas, en el triunfo de la revolución, lo cierto fue que el Estado y el conjunto de sus Administraciones no se disolvieron. ¿Por qué? Porque los anarquistas de la CNT vendieron como exclusivamente suyo un triunfo revolucionario que solo dominaron parcialmente en Barcelona. Y es que la CNT no poseía la fuerza afiliativa y la adhesión social suficiente para liderar la situación política y revolucionaria de Cataluña. En este sentido, hay que relativizar la imagen del Comité de Milicias Antifascistas de Cataluña como Gobierno alternativo y paralelo a la Generalitat. Ciertamente, a lo largo del verano del 1936 el Comité de Milicias Antifascistas, constituido el 21 de julio de 1936, contaba con la participación de los partidos del Front d'Esquerres y las organizaciones sindicales. Sin embargo, se constituyó administrativamente como una institución enmarcada dentro de la estructura administrativa y funcionarial de la Generalitat $^{37}$. En consecuencia, las decisiones tomadas por el Comité de Milicias siempre fueron sancionadas a través de decretos ley por el Gobierno de la Generalitat. Por todo ello, los empleados del Comité de Milicias Antifascistas de Cataluña se convirtieron en funcionarios de la Generalitat. Ahora bien, como muchos de sus empleados procedían de las bases no instruidas de la CNT, el Comité necesitó de funcionarios veteranos de la Generalitat para poder organizarlo administrativamente con eficacia. De esta forma, se creó una situación laboral marcada por la distinción entre los empleados, poco o nada letrados, de nueva incorporación como consecuencia de la victoria política cenetista y aquellos que eran funcionarios veteranos y letrados de la Generalitat ${ }^{38}$.

Ciertamente, se produjo un incremento de la función pública a lo largo del verano de 1936, pero al precio de un enorme intrusismo profesional. Esta

36 Marín (2005); Tavera (2005), y Martínez y Tavera (1998).

37 Murià (1985): 56, y Berger Mulattieri (2017).

38 Brusco (2003): 37-53, y Pozo (2004). 
situación fue especialmente lesiva en los ámbitos del orden público, el Ejército y la justicia. Por ejemplo, el Comité de Milicias se inmiscuyó en el terreno policial, puesto que en sus oficinas se decidían las listas de «fascistas» que debían ser fusilados o encarcelados. Y las patrullas de control, formadas por milicianos, obedecían sus instrucciones, que muy frecuentemente se reinterpretaban: por ejemplo, una orden de traslado de un detenido podía convertirse sin problemas en una reedición en versión ultraizquierdista de la «ley de fugas» aplicada a los cenetistas durante los años del «pistolerismo». En este contexto, los funcionarios de la Guardia de Asalto, la Guardia Civil y los Mossos de Escuadra interpretaron a las patrullas de control como unas fuerzas policiales intrusas y poco profesionales. Algo parecido sucedió con el Ejército. A los ojos de la población fiel a la República, el Ejército apareció como el culpable del inicio de la Guerra Civil y, por tanto, no se le podía tener ningún tipo de confianza. De esta manera, las columnas de milicianos se definieron como una alternativa militar "civilista» frente a la que consideraban cultura oficial del militarismo agresivo español. Así se convirtió en una realidad incuestionable la imagen del "pueblo en armas» contra el «fascismo", disciplinado y obediente con sus jefes. Nada más lejos de la realidad: cada columna hacía lo que quería y no se coordinaba con las otras. Las asambleas de milicianos constituían un absoluto dislate y cada uno atacaba como quería y cuando podía. En consecuencia, a cada ofensiva que se realizaba, las columnas sufrían un gran número de bajas con el consiguiente descenso de la moral de las tropas. En rigor, la nueva situación revolucionaria fue interpretada por los sectores más extremistas como una coyuntura en la cual se había puesto fin a la vetusta burocracia militar y sus funcionarios ${ }^{39}$.

Pero si notable resultó la falta de profesionalidad de las patrullas de control y de las columnas de milicianos, no menos lo fue la de los improvisados «jueces» que, durante el verano de 1936, se otorgaron el derecho de impartir la justicia revolucionaria en el bando republicano. De entrada, hay que destacar que el colapso de la justicia ordinaria resultó ser la característica más remarcable del verano de 1936, la cual fue sustituida por la justicia particular o privada de los comités o las patrullas de control. Así, en Cataluña más del $50 \%$ de los 8352 asesinatos que hubo durante la guerra se produjo antes de septiembre de 1936. Esto fue así en la medida en que fueron apartados de la función pública o eliminados físicamente la mayoría de los juristas de carrera por líderes o militantes sindicales y políticos de izquierda y de extrema izquierda, con un bajo nivel cultural y profesional, que actuaron a partir de la

39 Risques y Barrachina (2001): 19-68; Solé y Villarroya (1988); Cattini (2004), y Raguer (1999). 
sencilla premisa de declarar culpable a todo individuo sospechoso, no solo de haber participado directamente en la rebelión contra la República, sino de ser simpatizante de las derechas o católico, lo cual le convertía inmediatamente en culpable de haber apoyado la revuelta de los militares ${ }^{40}$.

El ascenso profesional de todo este conjunto de improvisados jueces y policías provocó la denuncia airada de técnicos y profesionales de carrera, fieles a la República, los cuales reclamaron que el Estado recuperase sus funciones gestoras de la res publica en todas sus dependencias e instituciones. Una de estas voces críticas fue la de Marià Rubió i Tudurí, hermano del arquitecto y urbanista Nicolau M.a Rubió i Tudurí. Marià publicó en 1937 (momento en que ya no resultaba tan peligroso denunciar los excesos parapoliciales del verano de 1936) un folleto titulado La justícia a Catalunya 19 juliol 1936-19 febrer 1937. Relació de les mesures provisionals adoptades pel Govern de la Generalitat per evitar l'enfonsament dels Tribunals de Justícia a Catalunya ${ }^{41}$. En este folleto se denunciaba el descontrol y la falta de profesionalidad de los nuevos funcionarios y jueces que se habían incorporado a la Administración de Justicia desde julio de 1936. Desde el punto de vista de Marià Rubió i Tudurí, la acción revolucionaria había confundido revolución con destrucción, aunque podía entender que la violencia revolucionaria contra los jueces había sido consecuencia de la mala imagen que tenía la Administración de Justicia entre los sectores populares. Estos consideraban que los jueces siempre actuaban o dictaban sentencia a favor de los sectores acomodados de la sociedad:

La parcialitat dels magistrats en matèria de delinqüència social. Unes vegades per sentiment anticatalà; altres vegades per por d'un o altre bàndol; altres vegades, per un instint persecutori, la mateixa justícia que absolvia els estafadors més coneguts, condemnava els reus de delictes socials. I quan no condemnava, es sabia tan públicament el perquè de l'absolució, que el prestigi de la toga en sortia malparat. Potser la paraula parcialitat no és prou justa. En realitat es titllava els jutges d'esser un tribunal de classe ${ }^{42}$.

Por mucha sed de justicia que existiese entre los sectores obreros y campesinos, Marià Rubió no podía justificar, desde su posición de intelectual-profesional de clase media, que las masas libertarias asaltaran los edificios emblemáticos de la judicatura como el Palau de Justícia o los colegios de abogados y notarios. Ante el secuestro de la justicia por parte del pueblo, Rubió

40 Juliá (1999): 73; Vidal (2004), y Pagès i Blanch (2015)

41 Rubió i Tudurí (1937).

42 Ibid.: 6-11. 
defendió como mal menor que la Generalitat diese carta de legalidad a todo este proceso de transformación de la función pública judicial a través del decreto del 17 de agosto de 1936 por el cual se creaba una Oficina Jurídica:

encarregada de resoldre gratuïtament les consultes que formulin, verbalment o per escrit, les organitzacions obreres i els particulars interessats, relatives a la interpretació i aplicació del nou Dret. [...] En la pràctica l'Oficina Jurídica no actuà dins del marc del Decret, cosa fonamentalment impossible perquè el nou Dret a què es refereix el Decret no existia en aquell moment ni existeix ara, parlant amb propietat i en bona tècnica jurídica. Erigits els lletrats que en nom de la CNT ocuparen el Palau de Justícia en Tribunal Revolucionari, del Decret de 17 d'agost n'utilitzaren el nom d'Oficina Jurídica i les atribucions que se li atorgaren, refusant allò que en el Dret suposava limitacióo ${ }^{43}$.

Así, la Oficina Jurídica constituyó más un eufemismo que validó la justicia revolucionaria aún por plasmar en papel escrito frente a la justicia ordinaria que había funcionado hasta la primavera de 1936. Por tanto, la Generalitat contraatacó con otro decreto de 18 de septiembre de 1936 por el cual se establecía que las instancias judiciales propias del Estado republicano constituido en 1931 (audiencias territoriales, audiencias provinciales y tribunales ordinarios) continuasen realizando sus labores habituales, siempre y cuando se adaptasen a la nueva situación revolucionaria. Con esta lógica y ante la inexistencia escrita de las «leyes revolucionarias», los jurisconsultos de toda la vida y no depurados en 1936 continuaron impartiendo justicia a partir de los códigos legales vigentes durante los ańos previos a la Guerra Civil ${ }^{44}$.

\section{EL DILEMA DE LA CNT}

Sin embargo, aunque la CNT fue la diana de todas las críticas que la señalaban como la gran culpable de la debilitación de las instituciones del Estado republicano, lo cierto fue que la misma CNT devino en un foro muy activo de debate entre los libertarios que abrazaron la causa estatista y, por consiguiente, partidarios de contratar funcionarios de fidelidad anarcosindicalista, y aquellos que consideraban que esta tendencia estatista y funcionarial supondría la muerte del espíritu revolucionario del verano de 1936.

$43 \quad$ Ibid.: 14.

44 Cuéllar (2004): 168. 
De este modo, los problemas internos de la CNT durante la guerra derivaron de la deficiente cauterización de la herida que supuso la fractura entre los partidarios del gubernamentalismo y aquellos que apostaron por la conquista absoluta del poder revolucionario a las manos únicas y exclusivas de la Confederación Nacional del Trabajo. Entre los primeros cabe destacar, principalmente, todos aquellos que disfrutaron de la condición de ministro, de consejero o de altos cargos de la Administración central y autonómica. Entre los segundos tomó un notable protagonismo la agrupación «Los Amigos de Durruti», que se convirtió en portavoz ocasional de todos aquellos sectores libertarios que habían quedado al margen de los cargos directivos de la CNT y de los puestos de poder de la Administración pública republicana central y autonómica. Sin embargo, para más paradoja, los sectores antigubernamentalistas dominaban, desde julio de 1936, comités locales, columnas de milicianos y entidades públicas y económicas, como Telefónica. A tener presente: dominaban esferas de poder que se habían convertido en Estado. Por tanto, ¿cuál era el problema? ¿El antigubernamentalismo en sí mismo? No. El problema residía en los socios de viaje que habían aceptado los gubernamentalistas para realizar la guerra y la revolución, así como el certificado de supervivencia que le habían otorgado al «viejo» Estado republicano. Los antigubernamentalistas apostaban de una forma muy difusa por una revolución estrictamente comunalista (municipalista), sin autoridad central, con funcionarios locales, aunque negaran el término, estrictamente libertarios y en un marco de organización, digamos estatal, totalizado por el sindicato. Dicho de otra forma, la división en el seno del anarcosindicalismo patentizaba la existencia de dos puntos de vista completamente diferentes sobre cómo se había de gestionar la promoción social y profesional de todos los cuadros, militantes y adherentes de la CNT en el nuevo «orden revolucionario». Esta dualidad de pareceres planteaba a los círculos libertarios una serie de interrogantes de difícil respuesta. El primero: ¿cómo debía ser el Estado republicano, en caso de continuar consintiendo la CNT su existencia? En segundo lugar: en caso de seguir existiendo el Estado, ¿cuál debía ser la relación de este y de sus diferentes Administraciones con el magma de comités, columnas de milicianos, colectividades y los múltiples servicios gestionados por los libertarios? Porque, en último término, todos estos servicios venían a definir todo lo que podríamos denominar como la sociedad civil libertaria (dominada por el sindicato) y que, para los sectores más radicales del anarquismo catalán, debía suponer en un futuro no muy lejano la alternativa real de gestión estatal o paraestatal al propio Estado republicano ${ }^{45}$.

45 Aisa (2006). 
Ciertamente, los sectores más antigubernamentales de la CNT observaron que el mantenimiento del Estado republicano y de sus Administraciones había sido un error letal para la teórica hegemonía cenetista. Además, denunciaron que, durante los primeros meses de la guerra, tanto el Estado republicano como la autonomía regional catalana habían crecido considerablemente en el ámbito orgánico y en el número de empleados públicos. En consecuencia, desde el punto de vista del antigubernamentalismo cenetista se tomó plena conciencia de que la dirección de la CNT había ayudado al Estado republicano y a sus diferentes Administraciones a convertirse en unos rivales poderosos para la hegemonía de la sociedad civil libertaria. Por ello, las acciones violentas de los llamados «incontrolados» tenían como objetivo marcar el territorio de influencia y de gestión auténticamente libertaria. En definitiva, la lucha por los monopolios de la oferta pública y privada del trabajo y del orden público (y, por tanto, del funcionariado de las consejerías de Seguridad Interior y de Defensa) conformaron, al margen de los discursos políticos sobre la guerra y la revolución, el telón de fondo de los acontecimientos violentos que condujeron a los Hechos de Mayo de 1937.

La lucha por el monopolio de la Administración pública y revolucionaria fue complementaria al de la afiliación sindical. La dirección de la CNT, una vez aceptada la lógica del gubernamentalismo, no dudó en competir ya de forma abierta por la conquista de aquellos espacios sociales y laborales que la central socialista UGT siempre había considerado como bastiones afiliativos propios (servicios, pequeños patrones agrarios e industriales). De esta forma, la Confederación Nacional del Trabajo, despojada de sus tabús discursivos clásicos, también apostó, como la UGT, por atraerse a la denominada "pequeña burguesía propietaria», sobre todo rural, y especialmente aquella que cultivaba su parcela de tierra no para sacar un beneficio monetario en el mercado, sino para el propio autoconsumo familiar: "A los pocos días de producirse el criminal levantamiento fascista, nosotros decíamos que nada tenía que temer la pequeña burguesía. [...] Únicamente podemos aceptar como pequeño burgués todo aquel que tenga un negocio, o bien un pedazo de tierra, y solamente él y sus familiares trabajen en el mismo; pero tan pronto tenga necesidad de un segundo, ya no es posible catalogarlo de pequeño burgués» ${ }^{46}$.

Como los círculos psuquistas, la dirección y la publicidad cenetista oficial y progubernamental apostó por la defensa del pequeño negocio familiar, tanto agrario como industrial, que había sido característico del tejido económico catalán desde los inicios de la Revolución Industrial. Ahora bien,

46 «La Revolución y la Guerra, al día / La pequeña burguesía», Solidaridad Obrera, 7-21937, p. 5. 
desde la lógica anarquista se entendía como pequeño negocio familiar aquel que no tenía empleados ajenos a la familia, porque, de lo contrario, habría que hablar de un negocio netamente «burgués» $\mathrm{o}$, dicho de otra forma, de características capitalistas con explotadores y explotados. Así, los teóricos libertarios distinguieron entre el pequeño burgués «bueno» y revolucionario, que no tenía asalariados, y el pequeño burgués «malo» y contrarrevolucionario, que sí tenía asalariados y, además, los explotaba. Esta distinción tomó pleno sentido cuando los cenetistas denunciaron, durante los primeros meses de 1937, la incorporación masiva de aquellos que llamaron como pequeńos propietarios «fascistas» a las filas de la UGT. Esta incorporación de «fascistas» al ugetismo catalán se habría producido, según las críticas anarcosindicalistas, a raíz de la adhesión del GEPCI (Gremios y Entidades de Pequeños Comerciantes e Industriales) a la UGT. Además, la prensa anarcosindicalista denunció las supuestas presiones que habrían efectuado los patrones adheridos al GEPCI sobre sus trabajadores con el objetivo de incorporarlos también a la UGT ${ }^{47}$.

Las críticas de la CNT al GEPCI y, de rebote, a la UGT no hacían otra cosa que esconder el fracaso cenetista en la incorporación de la pequeña burguesía propietaria de Cataluña en la órbita libertaria. Ante este fracaso, la propaganda anarcosindicalista redefinió el sentido de la incorporación del GEPCI a la UGT. Ahora ya no era un sector con un gran potencial revolucionario, sino un nido de contrarrevolucionarios que con su incorporación a la UGT habían desvelado el verdadero significado de la central socialista: el de refugio de los enemigos de la revolución ${ }^{48}$.

Detrás de la filigrana conceptual de los teóricos libertarios sobre qué era o no era un pequeño burgués revolucionario se cernía la sombra de los Hechos de la Fatarella de enero de 1937. Estos se iniciaron con la negativa de los pequeńos propietarios agrarios del pueblo tarraconense de la Fatarella, mayoritariamente afiliados a la UGT, a incorporar sus tierras a la colectivización cenetista del pueblo. Las presiones y requisas sufridas por los pequeńos propietarios a manos de los colectivistas libertarios condujo a una revuelta de los pequeños propietarios que fue reprimida, con ejecuciones sumarias, por las patrullas de control integradas en buen número por elementos anarquistas ${ }^{49}$.

47 «La revolución y la guerra, al día / La GEPCI y los trabajadores», Solidaridad Obrera, 3-4-1937, p. 5, y Ballester (1998): 205-217.

48 M. Ginés, "La pequeña burguesía empieza a incorporarse a la revolución», Solidaridad Obrera, 6-4-1937: 10; y "De cara a la guerra / La pequeña burguesía y el proletariado», Solidaridad Obrera, 7-4-1937, p. 1.

49 Termes (2005). 
Ante la desmesura represiva ejercida por las patrullas y militantes anarcosindicalistas de la Fatarella, la dirección cenetista progubernamental profundizó en su renovada visión tecnocrática y profesionalizada del mundo laboral, y en la cual tenía cabida la pequeńa propiedad agraria, pero también una redefinición de lo que era un tecnócrata y un funcionario o ambas cosas a la vez en un contexto revolucionario. De entrada, se aceptaba sin problemas encuadrar funcionarios en el Sindicato Único de Funcionarios de la Generalitat de Catalunya (SUFGC)-CNT. No solo eso, sino que se destacaba cómo los funcionarios de adscripción libertaria, desde julio de 1936, se habían desenvuelto modélicamente en sus funciones laborales en todas las Administraciones y servicios públicos como los tranvías y los autobuses de Barcelona. Así, antes de la Guerra Civil, la gestión de tranvías y autobuses había recaído en manos privadas previo concurso público organizado por el Ayuntamiento de Barcelona. Y de hecho, alguno de estos concursos había degenerado en polémica a raíz de las acusaciones a miembros de ERC por haber manipulado la concesión de los servicios de transportes a empresas y negocios para que se beneficiaran sus «amigos políticos». A raíz de la revolución, la gestión pasó a manos de los sindicatos, fundamentalmente del Sindicato Único de Transportes de la CNT, la cual se basó en la reducción del personal burocrático innecesario a fin de reducir gastos. Aun así, la Generalitat dispuso simbólicamente de un delegado encargado de supervisar la gestión sindical ${ }^{50}$. Por otro lado, la prensa confederal señalaba que la organización del trabajo en los servicios diseñada por los libertarios había potenciado los méritos tecnocráticos como vía de promoción profesional:

En el municipio hay empleados no sólo con un oficio, sino hasta con carrera, y están de ordenanzas... Esto también se concluirá. El hombre irá a trabajar allá donde pueda ser más útil, donde sus conocimientos le hagan más provechoso en beneficio de la colectividad. Los empleados que conocen un oficio, pasarán a ejercerlo en el taller municipal, para acoplarlos a su antigua profesión, si tienen aptitudes para ello. El Municipio no ha de ser un nido de burócratas, sino un lugar de trabajo, en el que cada cual desenvuelva sus aptitudes; sólo así podrá ser efectivo el rendimiento de la labor ${ }^{51}$.

50 "Reportajes de "Solidaridad Obrera" / El espíritu constructivo de la CNT. Cómo ha intensificado la Revolución la industria de los autobuses», Solidaridad Obrera, 25-121936, p. 4; o "Reportajes de "Solidaridad Obrera" / El espíritu constructivo de la CNT. La labor de la CNT ha mejorado el servicio de tranvías de Barcelona», Solidaridad Obrera, 26-12-1936, p. 4.

51 «La labor de la CNT en el consejo municipal / Cómo se ha trabajado en los servicios», Solidaridad Obrera, 14-4-1937, p. 2. 
El discurso oficial de la CNT apostó, por tanto, por una organización tecnocrática del trabajo, tanto en el ámbito de gestión privada-sindical como en el de la Administración pública, de tal forma que la experiencia profesional y los títulos académicos debían permitir situar a los trabajadores y empleados en los trabajos adecuados en función de sus aptitudes y conocimientos ${ }^{52}$. Esto significaba un ataque frontal contra el diletantismo y el intrusismo profesional que se había impuesto, entre el verano de 1936 y la primavera de 1937, en la organización del trabajo en el bando republicano y, especialmente, en el sector de los servicios públicos. Ciertamente, muchos trabajadores manuales se aprovecharon de su condición de líderes sindicales o políticos para optar a trabajos propios del mundo de los servicios, algunos de los cuales hubieran requerido para ejercerlas el título universitario (sobre todo dentro del mundo de la judicatura). Sin embargo, el triunfo del diletantismo y el intrusismo en la función pública había sido fruto de una interpretación bastante particular de determinados sectores del obrerismo radical, fueran del anarcosindicalismo como del ugetismo, sobre cómo debía interpretarse el concepto de «justicia social». Según esta interpretación, los mejores puestos de la Administración tradicionalmente habían recaído en los «ricos» que, por sus posibilidades económicas, habían podido estudiar una carrera universitaria. Por el contrario, los «pobres» no habían podido disfrutar de una preparación académica oficial debido a la falta de recursos económicos: las familias obreras habían necesitado los sueldos de sus hijos para subsistir. Así, para el obrerismo radical, tanto gubernamentalista como antigubernamentalista, la revolución habría subsanado de raíz esta «injusticia» al «echar» a los "ricos» de sus cómodos puestos de trabajo (insinuando, incluso, que no serían auténticos profesionales, ya que por ser adinerados seguramente las autoridades académicas les habían regalado los títulos) para situar a los «pobres» que, sin estudios, seguro que también podían hacer competentemente las tareas más complicadas y especializadas ${ }^{53}$.

Ante el triunfo del diletantismo profesional, los círculos de técnicos y de intelectuales, fueran anarquistas, socialistas, comunistas o republicanos, reaccionaron corporativamente y reclamaron la necesidad de restaurar la meritocracia académica como requisito indispensable para acceder a un puesto de trabajo público o a un cargo de gestión administrativa. Esto significaba tener que devolver los obreros manuales a sus puestos de trabajo, donde no disfrutarían del poder y el «prestigio social» de los cargos de gestión de la Administración que habían «usurpado» en el verano de 1936. Lógicamente, esta visión de una tecnocracia menos diletante como gestora de la revolución debía

52 Juan P. Fàbregas «La tecnocracia y la revolución», Solidaridad Obrera, 2-5-1937, p. 3.

53 Díez (2010). 
confrontar a los líderes de la CNT y de la UGT con sus respectivas bases, punto que debe interpretarse como una de las causas de los Hechos de Mayo de Barcelona de 1937.

\section{CONCLUSIÓN}

En conclusión, la Guerra Civil desató, aún más que en el periodo 19311936, la disputa por los puestos de trabajo de la Administración pública en Cataluña. En este caso concreto, ERC quiso construir desde 1931 una Administración autónoma con un funcionariado profesional, aunque fiel políticamente a sus postulados. Esta tendencia a la politización de la función pública se vio incrementada durante la Guerra Civil con el asalto de las masas y de los líderes sindicales revolucionarios a los puestos de trabajo y de dirección de las diferentes Administraciones públicas y de los nuevos organismos de poder revolucionario. La consecuencia fue el aumento de la función pública en Cataluña, pero a costa de una menor profesionalización de sus empleados. Como consecuencia, la represión franquista en la Administración local catalana se justificó, de forma oportunista, en la idea de poner fin a la falta de profesionalidad del funcionariado de Cataluña $a^{54}$.

\section{Bibliografía}

Adroher, C. (1986). La Guerra Civil a les comarques gironines (1936-1939). Girona: Cercle d'Estudis Històrics i Socials.

Aisa, F. (2006). La cultura anarquista a Catalunya. Barcelona: Edicions de 1984.

Alberdi, R. (1983). Política i ensenyament a Barcelona. L'Escola del Treball (1913-1930). Recerques, 14, 97-112.

Alquézar, R. (1986). L'Ajuntament de Barcelona en el marc del Front d'Esquerres. Barcelona: Columna.

- (1988). Els conflictes a l'Ajuntament de Barcelona durant la II República. L'Avenç, $116,16-22$.

Assemblea General de la Lliga Regionalista (1933). Lliga Catalana. Un partit una política. Barcelona: Tipografia Emporium.

Bahamonde Magro, A. (1992). Pascual Madoz y la modernización de la ciudad de Madrid: La Peninsular, empresa inmobiliaria, 1861-1883. En J. L. García Delgado. Las ciudades en la modernización de España. Los decenios interseculares (pp. 379-404). Madrid: Siglo XxI.

54 Gil Garrusta (2017). Como comparativa en el País Vasco: Ipiña Bidaurrazaga (2017). 
Balcells Pujol, E. y Sabater, J. (1996) La Mancomunitat de Catalunya i l'autonomia. Barcelona: Proa.

Ballester, D. (1998). Els anys de la guerra. La UGT de Catalunya (1936-1939). Barcelona: Columna-Fundació Josep Comaposada.

Bases per a la Constitució Regional Catalana. Manresa març de 1892. (1991). Vic: Institut Universitari d'Història Jaume Vicens i Vives-Eumo Editorial.

Berger Mulattieri, G. (2017). Les Milicies Antifeixistes de Catalunya (21 de juliol-31 de desembre de 1936) [tesis doctoral inédita]. Barcelona: Universitat de Barcelona.

Bernecker, W. L. (1982). Colectividades y revolución social. El anarquismo en la guerra civil española 1936-1939. Barcelona: Crítica.

Bonamusa, F. (1974). El Bloc Obrer i Camperol: Els primers anys (1930-1932). Barcelona: Curial.

Boyd, C. P. (1990). La politica pretoriana en el reinado de Alfonso XIII. Madrid: Alianza Editorial.

Brusco, R. (2003). Les milícies antifeixistes i l'exèrcit popular a Catalunya (1936-1937). Barcelona: Edicions El Jonc.

Calvo, J. J. (1974). La Capitania General de Catalunya de 1875 a 1931: la actuación de los capitanes generales [tesis doctoral]. Barcelona: Universidad de Barcelona.

Cardona, G. (1983). El poder militar en la España contemporánea hasta la Guerra Civil. Madrid: Siglo xxI.

Carreras, A. (1990). Cataluña, primera región industrial de España. En J. Nadal y A. Carreras. Pautas regionales de la industrialización española (siglos XIX y XX) (pp. 260-295). Barcelona: Ariel.

Casals, X. (2013). Auge y declive del «partido militar» de Barcelona (1898-1936). Iberic@l, 4, 163-180. Disponible en: https://bit.ly/2SJsHFQ.

Casassas i Ymbert, J. (1980). Jaume Bofill i Mates (1878-1933). L'adscripció social i l'evolució politica. Barcelona: Curial.

- (1989). Intel.lectuals, professionals i politics a la Catalunya contemporània (1850-1920). Barcelona: Els Llibres de la Frontera.

Cattini, G. C. (2004). La violència revolucionària. Terror i repressió a la reraguarda. En J. M. Solé i Sabaté (dir.). La Guerra Civil a Catalunya (1936-1939) (vol. 1) (pp. 144-153). Barcelona: Edicions 6.

Clara, J. (2004). La revolució a Girona. «Ara més que mai, visca la República!». En J. M. Solé I Sabaté. La Guerra Civil a Catalunya (1936-1939) (vol. 1) (pp. 192-193). Barcelona: Edicions 62.

Cruells, M. (1978). La societat catalana durant la guerra civil. Crònica d'un periodista polític. Barcelona: EDHASA.

Cuéllar, J. (2004). Àngel Samblancat, l'arbitrarietat de l'Oficina Jurídica. En J. M. Solé i Sabaté. La Guerra Civil a Catalunya (1936-1939) (vol. 1) (pp. 165-169). Barcelona: Edicions 62.

Deu i Baigual, E. (1990). La indústria tèxtil llanera de Sabadell, 1896-1925. Sabadell: Col. legi de Doctors i Llicenciats. Delegació de Sabadell.

Díez, X. (2010). Venjança de classe. Causes profundes de la violència revolucionària a Catalunya el 1936. Barcelona: Virus. 
Diputación Provincial de Barcelona. (1915). Memòria de l'actuació i organització de l'Escola de Funcionaris d'Administració Local. Barcelona: Impedides Casa Provincial de Caritat.

Duarte, A. (1989). Mayordomos y contramaestres. Jerarquía fabril en la industria algodonera catalana, 1879-1890. Historia Social, 4, 3-20.

Duarte i Montserrat, C. (1984). Els problemes del llenguatge administratiu català. Serra d'Or, 294, 11-12.

Durgan, A. Ch. (1996). BOC 1930-1936. El Bloque Obrero y Campesino. Barcelona: Laertes.

García Delgado, J. L. (1992). Madrid en los decenios interseculares: la economía de una naciente capital moderna. En J. L. García Delgado. Las ciudades en la modernización de España. Los decenios interseculares (pp. 405-414). Madrid: Siglo XXI.

García de Enterría, E. (1972). La Administración española. Madrid: Alianza Editorial.

Gil Garrusta, M. (2017). Barcelona al servei del Nuevo Estado. De puració a l'Ajuntament durant el primer franquisme. Vic-Barcelona: Eumo Editorial-Ajuntament de Barcelona.

Gimeno, M. (1987). Revolució, guerra i repressió al Pallars (1936-1939). Barcelona: Publicacions L'Abadia de Montserrat.

Ipiña Bidaurrazaga, A. (2017). La depuración de las empleadas y empleados municipales en Bizkaia durante la Guerra Civil y la dictadura franquista (1936-1967). Vitoria: Instituto Vasco de Administración Pública.

Joaniquet, A. (1955). Alfonso Sala Argemí. Conde de Egara. Madrid: Espasa-Calpe.

Juliá, S. (1992). En los orígenes del gran Madrid. En J. L. García Delgado (ed.). Las ciudades en la modernización de España. Los decenios interseculares (pp. 415-432). Madrid: Siglo Xxi.

(1999). Victimas de la Guerra Civil. Madrid: Temas de Hoy.

Leval, G., Souchy, A. y Cano Ruiz, B. (1982). La obra constructiva de la revolución española. México: Editorial Ideas-Editores Mexicanos Unidos.

López Rodó, L. (1963). La Administración Pública y las transformaciones socioeconómicas. Madrid: Real Academia de Ciencias Morales y Políticas.

Lladonosa i Vall-Llebrera, M. (1988). Catalanisme i moviment obrer: el CADCI entre 1903 i 1923. Barcelona: Publicacions L'Abadia de Montserrat.

Llorens i Vila, J. (1992). La Unió Catalanista i els orígens del catalanisme politic. Dels orígens a la presidència del Dr. Martí i Julià (1891-1903). Barcelona: Publicacions L’Abadia de Montserrat.

Marfany, J. Ll. (1987). Aspectes del modernisme. Barcelona: Curial.

- (1995). La cultura del catalanisme. Barcelona: Empúries.

Marín, D. (2005). Ministros anarquistas. La CNT en el gobierno de la II República (19361939). Barcelona: Debolsillo.

Martínez Fiol, D. (1999). Surrealisme i marxisme a Catalunya (1923-1932). Locus Amoenus, 4, 239-248. Disponible en: https://doi.org/10.5565/rev/locus.96.

- (2001). Daniel Domingo Montserrat (1900-1968). Entre el marxisme i el nacionalisme radical. Barcelona: Publicacions L’Abadia de Montserrat.

(2006). La sindicació dels funcionaris de la Generalitat de Catalunya (1931-1939) [tesis doctoral]. Barcelona: Universitat Autònoma de Barcelona.

- (2008). Estatisme I antiestatisme a Catalunya (1931-1939). Rivalitats polítiques i funcionarials a la Generalitat. Barcelona: Publicacions L'Abadia de Montserrat. 
- (2010). Els sindicats de funcionaris de la Generalitat de Catalunya (1931-1939). Barcelona: Publicacions L'Abadia de Montserrat.

Martínez Fiol, D. y Esculies, J. (2017). L’Assemblea de Parlamentaris de 1917 i la Catalunya rebel. Barcelona: Generalitat de Catalunya-Centre d'Història Contemporània de Catalunya.

Martínez Fiol, D. y Tavera García, S. (1998). Corporativismo y revolución: los límites de las utopías proletarias en Cataluña (1936-1939). Historia Social, 32, 53-71.

Mayayo i Artal, A. (1986). La Conca de Barberà (1890-1939). De la Crisi Agrària a la Guerra Civil. Montblanc: Centre d'Estudis de la Conca de Barberà.

Molas, I. (1973). Lliga Catalana. Un estudi d'estasiologia (2 vols.). Barcelona: Edicions 62.

Monjo, A. (1999). L'economia, entre revolució i guerra. En B. de Riquer. Història, política, societat i cultura dels Països Catalans (vol. 9) (pp. 230-248). Barcelona: Enciclopèdia Catalana.

Murià, J. M. (1985). Vivències d'un separatista. Barcelona: El Llamp.

Nadal, F. (1987). Burgueses, burócratas y territorio. La política territorial en la España del siglo XIX. Madrid: Instituto de Estudios de Administración Local.

Nadal, J. (1975). El fracaso de la revolución industrial en España (1814-1913). Barcelona: Ariel.

Nadal i Oller, J. (1991). Història econòmica de la Catalunya contemporània (vol. 3). Barcelona: Enciclopèdia Catalana.

Pagès i Blanch, P. (2015). Justícia i Guerra Civil als tribunals de justícia a Catalunya (19361939). Barcelona: Base.

Pérez Francesch, J. Ll. (1988). Catalanisme, exèrcit espanyol i ordre públic: les Bases de Manresa. Barcelona. L'Avenç, 112, 44-49.

Pous i Porta, J. y Solé i Sabaté, J. M. (1988). Anarquia i República a la Cerdanya (1936-1939). El «Cojo de Málaga» i els Fets de Bellver. Barcelona: Publicacions L'Abadia de Montserrat.

Pozo, J. A. (2004). La formació del poder revolucionari. Els Comitès de Milícies Antifeixistes de Catalunya. En J. M. Solé i Sabaté. La Guerra Civil a Catalunya (1936-1939) (vol. 1) (pp. 93-99, 103-107, 112-113 y 115). Barcelona: Edicions 62.

Prats i Armengol, F. (1990). La ciutat de Tremp durant la Segona República i la Guerra Civil (1931-1938). Barcelona: Rafael Dalmau.

Puy, J. (1983). Alfons Sala i Argemí. Industrial i politic 1863-1945. Terrassa: Arxiu Tobella.

Raguer, H. (1999). Les víctimes: persecució i repressió. En B. de Riquer (dir.). Història, política, societat $i$ cultura dels Països Catalans (pp. 252-269). Barcelona: Enciclopèdia Catalana.

Ramos y Bengoechea, S. (1989). La patronal catalana y la huelga de 1902. Historia Social, 5, 77-95.

Risques, M. (1995). El govern civil de Barcelona al segle XIX. Barcelona: Publicacions L'Abadia de Montserrat.

Risques y Barrachina, C. (2001). Procés a la Guàrdia Civil. Barcelona (1939). Barcelona: Pòrtic.

Romero Maura, J. (1989). «La rosa de fuego». El obrerismo barcelonés de 1899 a 1909. Madrid: Alianza Universidad.

Rubió i Tudurí, M. (1937). La justicia a Catalunya 19 juliol 1936 - 19 febrer 1937. Relació de les mesures provisionals adoptades pel Govern de la Generalitat per evitar l'enfonsament dels Tribunals de Justícia a Catalunya. Barcelona: Antecedents i Documents. 
Sagués San José, J. (2004). Lleida la Roja. El poder obrer a la capital de la Terra Ferma. En J. M. Solé i Sabaté. La Guerra Civil a Catalunya (1936-1939) (vol. 1) (pp. 174-179). Barcelona: Edicions 62.

Sarrión i Gualda, J. (1982). Història de l'Escola d'Administració Pública de Catalunya (19121939). Barcelona: Generalitat de Catalunya.

Seidman, M. (2002). A ras de suelo. Historia social de la República durante la Guerra Civil. Madrid: Alianza.

Sirera Miralles, C. (2011). Un titulo para las clases medias. El Instituto de Bachillerato Lluis Vives de Valencia, 1859-1902. València: Universitat de València.

Smith, A. (1995). La guerra de las continuas. Cambio tecnológico y estrategias sindicales en la industria algodonera catalana, 1889-1914. Sociología del trabajo, 24, 121-151.

— (1996). Trabajadores «dignos» en profesiones «honradas»: los oficios y la formación de la clase obrera barcelonesa (1899-1914). Hispania, 193, 655-687.

Solà, P. (1978). Els ateneus obrers i la cultura popular a Catalunya (1900-1939). L’Ateneu Enciclopèdic Popular. Barcelona: La Magrana.

Solé i Sabaté, J. M. y Villarroya, J. (1987). L'exèrcit espanyol i el fet català, 1898-1939. L'Avenç, 100, 92-95.

- (1988). La repressió a la reraguarda de Catalunya (1936-1939) (2 vols.). Barcelona: Publicacions L'Abadia de Montserrat.

- (1990). L'exèrcit i Catalunya (1898-1936). La premsa militar espanyola i el fet català. Barcelona: Llibres de l'Índex.

Tatjer, M. (1995). Evolució demográfica. En J. Sobrequés i Callicó (dir.). Història de Barcelona. 7. El segle XX. I. De les annexions a la fi de la guerra civil (pp. 71-122). Barcelona: Ajuntament de Barcelona-Enciclopèdia Catalana.

Tavera, S. (2005). Federica Montseny. La indomable (1905-19942. Madrid: Temas de Hoy.

Termes, J. (2005). Misèria contra pobresa. Els fets de la Fatarella de gener de 1937: un exemple de resistència pagesa contra la col.lectivització agrària durant la Guerra Civil. Catarroja-Barcelona: Afers, 2005.

Tubella, I. (1979). Jaume Compte i el Partit Català Proletari. Barcelona: La Magrana.

Ucelay-Da Cal, E. (1978). La crisi dels nacionalistes radicals catalans (1931-1932). Recerques, 8, 159-206.

- (1982). La Catalunya populista. Imatge, cultura i politica en l'etapa republicana (19311939). Barcelona: La Magrana.

- (1984). «El mirall de Catalunya»: models internacionals en el desenvolupament del nacionalisme i del separatisme català. Estudios de Historia Social, 28-29, 213-219.

(1987). La Diputació i la Mancomunitat: 1914-1923. En B. de Riquer. Història de la Diputació de Barcelona (vol. 2) (pp. 36-259). Barcelona: Diputació de Barcelona.

Ucelay-Da Cal, E. (2001). Llegar a capital: rango urbano, rivalidades interurbanas y la imaginación catalanista en la España del siglo xx. En A. Morales Moya (coord.). Las claves de la España del siglo XX. Ideologías y movimientos políticos (pp. 221-263). Madrid: Sociedad Estatal del Milenio.

Vallverdú, F. (1970). Dues llengües: dues funcions? Per una història lingüistica de Catalunya. Barcelona: Edicions 62.

— (1972). Ensayos sobre bilingüisme. Barcelona: Ariel. 
- (1990). L'ús del català: un futur controvertit. Qüestions de normalització lingüistica al llindar del segle XXI. Barcelona: Edicions 62.

Vidal, C. (2004). Checas de Madrid. Las cárceles republicanas al descubierto. Barcelona: Debolsillo.

Villacorta Baños, F. (1989). Profesionales y burócratas. Estado y poder corporativo en la España del siglo XX, 1890-1923. Madrid: Siglo Xxi.

Vinyes i Ribes, R. (1983). La Catalunya internacional. El frontpopulisme en l'exemple català. Barcelona: Curial.

Yáñez, C. (1986). L'emigració guixolenca a Amèrica durant el segle XIX. Plecs d'Història Local, 6, 82-89. 